\title{
The Facilitation of Child Development in a Japanese Nursery School
}

\author{
Christina Ellensohn
}

\begin{abstract}
This paper aims to explore the topic of facilitating children's development in a Japanese day-care centre (hoikuen). The research is based on a case study with participant observation in the daycare facility Minami Ōsawa Nursery School in Tōkyō. After a short overview on preschool education in Japan and an introduction to Minami Ōsawa Nursery School, the three main topics of child development around the age of five years-cognitive, social-emotional and motor developmentwill be further explored. These three areas will be defined more precisely in the context of the selfproclaimed aims and daily routine of the hoikuen team. Furthermore the importance of a child's autonomy is addressed.
\end{abstract}

Keywords: preschool education, day care, hoikuen, child development, Japan Japanese Nursery School." In Vienna Journal of East Asian Studies, Volume 4, eds. Rudiger Frank, Ina Hein, Lukas Pokorny and Agnes Schick-Chen. Vienna: Praesens Verlag, 2013, pp. 1-26. https://doi.org/10.2478/vjeas-2013-0001 


\section{Introduction}

With increasing work activity on the part of both parents, the demand for full-day care services such as nursery schools (hoikuen) for children is rising steadily. Since children spend most of the day in such institutions, the influence of the day-care team's educational work on the children's development is correspondingly wide. It is thus important to discuss the issue of facilitating child development in such centres in more detail.

In this paper I am concerned with the question of how preschool children are supported and facilitated in their development in a hoikuen 保育園. To answer this question, a detailed discussion is required of what the focus in the work of educators is and which targets and objectives are defined by the Ministry of Health, Labour and Welfare for full-day care centres. Further importance has to be given to the longer operating hours of a hoikuen and the accompanying changes in daily routine, compared to a kindergarten (yōchien 幼稚園). Since the children spend a significant period of time in the institution, its influence thus also extends to a wider range of areas in their development, such as the sleep-wake cycle, feeding, or the formation of trust in their peers and teachers.

The findings and insights I gained during my eight-month internship in a Japanese day-care facility through active participation and observation form the basis of this study. Carrying out participatory observation means participating in the everyday life of people, a group or institution either openly or in a less visible way. One observes, listens, asks questions and collects all the data that are available and could be important for the observer (Hammersley and Atkinson 1983: 2). Initially I was not sure if I would write my master's thesis on preschool education. However, my previous professional training as a kindergarten teacher and my knowledge of participatory observation gained through previous internships in Austrian kindergartens, prompted me to write down all my experiences and observations in the detailed style I was used to. I visited the facility once every week and on the special days when festivals were held, like Mochitsuki 餅付き ${ }^{1}$ or the summer festival. My focus lay mostly on the children of the DonDon group ${ }^{2}$ - the five-year-olds. But I also had contact with the younger children, especially during the free play period every morning.

Initially my observations were confined to the basic daily schedule, routines and rituals, which I wrote into my observation diary at the end of the day. Once I knew

1 A traditional gathering in January for the hoikuen's families to pound rice cakes and greet the New Year.

2 The Japanese term dondon どんどん is used to describe the fast pace at which children are able to run and learn at this age. All the other groups had names that described an aspect of their age group's respective development stage too, like the two-year-old group's yochiyochi よちよち, which describes their still shaky walking on two legs, or the three-year-old group's nazenaze なぜなぜ for the many questions they like to ask all day. 
the facility's basic processes, my observations became more detailed and comprehensive. Questions arising could often be answered through informal conversations with the teachers, and more often than not they talked spontaneously with me about recent happenings in the playground or expressed their views on individual children's behaviour and its causes.

\section{Preschool education in Japan}

Since the introduction of pre-primary education in Japan in the second half of the 19th century, the preschool sector has been divided into two broad categoriesyōchien and hoikuen. Initially, the two facilities were designed for different purposes and therefore subjected to two different ministries. Hoikuen, nursery schools fall under the administration of the Ministry of Health, Labour and Welfare (MHLW), whereas the Ministry of Education, Culture, Sports, Science and Technology (MEXT) is in charge of the yōchien, which corresponds to a kindergarten (JETRO 2005: 14; Ben Ari 1997: 7; Holloway 2000: 29). Yōchien were directed more towards children of the middle class and were particularly interested in cognitive promotion and the fostering of human relations, whereas hoikuen were intended for children of the working class and were more focused on safety and cleanliness (Holloway 2000: 29). Through the years, the duties of a hoikuen were more and more altered and aligned themselves with the profile of the yochien. These days, hoikuen and $y \bar{o} c h i e n$ both offer the same educational and training opportunities, and the basic guidelines of the MHLW and the MEXT for preschool education are almost identical for both types (Holloway 2000: 29; Tobin, Hsueh, and Karasawa 2009: 140141).

While $y \bar{o}$ chien are usually open for half of the day and accept children aged four and five, hoikuen are open all day and accept children from the age of a few months up to six years (Ben Ari 1997: 7; DeCoker 1993: 46). The group size in yōchien and hoikuen is of course dependent on the number of children attending the facility, but the maximum in the hoikuen stands at thirty children aged three to five per teacher and in the yōchien at forty per teacher (Peak 1991: 56; Lewis 1995: 9; Boocock 1989: 46; Tobin, Hsueh, and Karawasa 2009: 129). In the case of infants, the teacher/child ratio lies at 1:3, between ages one to two at 1:6, and for three-year-olds at 1:20 (Hendry 1986a: 120-121; JETRO 2005: 9).

It is important to note the differences between the two institutions, because the fact that the children attend a hoikuen all day and not only half a day brings with it, for example, a much more complex set of tasks that need to be addressed. They include not only the achievement of educational goals, but also daily routine tasks such as cooking, eating, sleeping and the long periods of care (Ben Ari 1997: 8; Hashimoto 1992: 136; Tobin, Hsueh, and Karasawa 2009: 127). A hoikuen needs 
more space and staff than a yōchien. Special premises for the infants and toddlers such as a baby-changing area, a kitchen for lunch and snack preparation, futons for nap time and sufficient staff to cover the long care hours every day from 7 a.m. to 7 p.m.; all these are extra requirements that a hoikuen has to meet in addition to the officially prescribed educational goals.

The staff of the preschool facilities is almost exclusively female with a percentage of 94 percent, and about half of the teachers are under the age of 27 . The young women have completed at least a two-year college or university educational course and passed an examination in order to work as a qualified teacher (Boocock 1989: 55; DeCoker 1993: 47; Holloway 2000: 30; Lewis 1995: 9; Peak 1991: 51-52; Zhou, Oishi, and Ueda 2002: 419).

If asked about their duties and responsibilities, the answer given by most teachers is the creation of a suitable environment for the children so that they are able to reach out to each other and thus interact in the group. Large group sizes are a welcome factor here because the teachers are not tempted to build strong one-to-one relationships with individual children, but seek to encourage them to socialise and interact with their peers (Peak 1991: 56; Tobin, Wu and Davidson 1987: 539). The teachers see their main task as teaching the children the basic skills of everyday life, such as getting dressed, eating and speaking correctly as well as giving them a sense of belonging in order to support the development of their social skills (Ben Ari 1996: 145). Ideally hoikuen are facilities where children are encouraged to connect with their environment and learn holistically by being offered various opportunities to experience life in all its aspects. A hoikuen should be a warm, welcoming and relaxing place for the children, to convey stability and to assist them in their emotional development (Hoffman 2000: 198).

Since children spend most of the day in a hoikuen, these institutions have a great influence on them, because of the precise daily routine and the educational work of the teachers. The children are able to experience different play scenarios and learning opportunities and they are encouraged to train their social and intellectual skills (Hendry 1986a: 121; Lewis 1995: 30-31; Ben Ari 1997: 67; Holloway 2000: 2).

\section{Minami Ōsawa Nursery School}

Minami Ōsawa Nursery School 南大沢保育園 was founded in 1985 and is located in Hachiōji八王子, a suburb of Tōkyō 東京, surrounded by several large housing complexes. In the neighbourhood there is a small park, an elementary school, a middle school and another hoikuen. The facility is managed by Mrs T., belongs to Kuzuryūkai 九頭竜会, the social services corporation, and enjoys a good reputation in the local area as well as with the local university. 
The opening hours are weekdays from seven o'clock in the morning until seven at night. The staff of the facility comprises 25 teachers, two qualified nutrition experts, a licensed cook and a nurse, as well as four further staff members in addition to the head Mrs T. The hoikuen building consists of a ground floor and an upper floor with a total space of $720.75 \mathrm{sq} \mathrm{m}$ as well as a large outdoor area with a size of 2607.76 sq m. The 131 children visiting Minami Ōsawa Nursery School are divided into six age groups: zero, one, two, three, four and five years. Each age group has its own group room which is used for playing, teacher-guided activities, lunch and nap time. The zero to two-year-old children are taken care of by the teachers on the upper floor, whereas the three older age groups play outdoor most of the time and only use their group rooms for the activities stated above. During my internship the group count was divided as follows:

$\begin{array}{ll}\text { Zero-year olds: } & 15 \text { children } \\ \text { One-year olds: } & 20 \text { children } \\ \text { Two-year olds: } & 21 \text { children } \\ \text { Three-year olds: } & 22 \text { children } \\ \text { Four-year olds: } & 25 \text { children } \\ \text { Five-year olds: } & 28 \text { children }\end{array}$

The teacher-child ratio was oriented on the respective age groups. Thus the group of the zero-year-olds had one teacher per three infants, the one-year-olds had one teacher per five toddlers and the two-year-olds one per six children. Downstairs teachers were divided into three per group room.

The main objective of Minami Ōsawa Hoikuen is described as the following:

Jōzu ni karada o tsukatte asobō 上手に体を使って遊ぼう

Let's play by using our bodies in a skilful way

(Shakai fukushihōjin kuzuryūkai 2012, \# hoiku mokuhyō nado)

The self-declared mission of the institution is to create an environment in which the children develop their skills independently and expand their innate vitality in a sufficient way. Mrs T. wants to provide a place in which a harmonious pattern of living together is set out and 'smiling faces prevail'. She cites the concrete values of the hoikuen, which are described on the homepage as follows:

1. It is important to have a harmonious team in which the strengths of each member are used. The teachers should challenge each other, thereby creating a highquality facility

2. Furthermore, the promotion of the expertise of the teachers is important. The social environment surrounding the children and their education should always 
be kept in mind and the teachers should be trustworthy partners of the parents in their children's education

3. Interpersonal relationships are a key point in the hoikuen. The relationships between people are to be valued, the social character of the children supported and the children, our next generation, involved in the cultural succession [of Japan]

4. Social and emotional competence should be expressed in enthusiasm and compassion. The sensitivity and the intellectual seed that each child holds, will be nurtured by profound experiences and situations in which one can share emotions with others

5. The hoikuen team never forgets the joy that its work brings and adheres to it with enthusiasm and pride (Shakai fukushihōjin kuzuryūkai 2010: \# hoiku mokuhyō nado $)^{3}$

The above points correspond mostly to the official specifications of the MHLW. In particular the importance of the pedagogical team's co-operation with the parents, the promotion of interpersonal relationships and support of the construction of a child's social-emotional competence are noted in the Hoikusho hoiku shishin (Guidelines for childcare in day-care centres) as specific and important points in the work of day-care facilities (Ministry of Health, Labour and Welfare 2008: 4, 13-14; Hamatani, Ōwada and Fujisaki 2001: 4-5).

Minami Ōsawa Hoikuen is headed by a married couple. The former director and founder of the facility is Mrs T.'s father, so it could be said that the hoikuen is a family-run establishment. Mrs T.'s father is a regular at the facility and turned into a kind of hoikuen-grandfather for the children throughout the years. He was often seen on the playground, gardening and doing small repairs with the children's enthusiastic help during my internship.

The dynamics in the team itself were alive and there was an open and friendly interaction among the teachers. The team consisted of young women under 30 and the atmosphere was filled with laughter and lots of activity. The few older and more experienced teachers were a haven of tranquillity in everyday life. It was striking that the older teachers were mostly quiet in the playground and observed, while the younger educators often were more active in response to the childrens' invitations to play. Because of these two very opposite behavioural characteristics the prevailing mood in the hoikuen seemed balanced and had a positive and steadying effect on the conditions in which the children were playing, because they always knew whom of the teachers to turn to in which situation. This is an observation Hashimoto also makes and discusses in her book on Female Labour and Childcare (Hashimoto 1992: 137).

3 This and all other translations into English in this paper are by the author. 


\section{Daily routine in the Minami Ōsawa Nursery School}

During the morning greeting at 9:30 a.m. the children gather outside or in their classrooms, greet each other with a short song and rhyme and bow to the teacher and the two tōban 当番. ${ }^{4}$ The ritual can easily be carried out together with other groups, as the song of welcome is always the same for each age group. Following the greeting the teacher calls each child's name in order to check who is present. During the morning greeting session the children have the chance to look for possible playmates for the next round of free play, because often the desired partners cannot be found easily in the large playground. After the morning routine the children are dismissed into the next round of free play or the teacher's guided activity.

The children in Minami Ōsawa Nursery School spend a large part of the day outdoors and play with other children from all ages. According to one teacher, the head of the hoikuen holds the view that children should play as often as possible in the open air in order to be healthy and happy. The children are thus in the playground even on very hot days when the sun is burning in the sky. On those days, play is not on their agenda and they prefer to stay in the few shady areas and to rest until their teachers call them. Free play on the playground is moved indoors only on rainy or extremely cold days and can occasionally be interrupted by a teacher for a short guided 'impulse activity'. These impulse activities usually are related to a current event, for example the hatching of the young of a praying mantis. In this case the teacher took the small plastic terrarium outside to the playground and called the children of her group, the DonDons, to her. The children engaged in a long, happy search for good places in the bushes to release the young into nature. On other days, the plum tree's fruit is harvested together with the director's father; or the caterpillars in the terrarium are fed with fresh leaves. The children especially like naturerelated activities involving insects. Whenever they find something of interest, they rush to the teacher to show their treasure and occasionally the teacher uses the children's interest to convert what has been found into a small project. Impulses are not planned beforehand but incorporated spontaneously into the everyday routine as needed and wanted.

Games material, such as board games or a wide variety of construction materials as I know them from Austrian kindergartens, is used seldom and sparingly. Only on the few days when free play takes place indoors are different construction materials, doll's food made out of wood, and paper and crayons provided for the children. Sometimes the children play with cards, make handicrafts with strips of paper or

4 The two children on tōban duty that day. A tōban's tasks consist, for example, of greeting the children every morning, bidding them farewell in the afternoon or distributing the food at lunch time. Children on tôban duty also like to help others solve small disputes and quarrels during free play. 
look at picture books. The play material for indoors is usually limited to three things and is not generally accessible but is distributed by the teachers.

The guided activity, which lasts an average of 30 to 45 minutes, is a phase of concentration and obligatory for every child. Activities that are conducted are, for example, rhythmicity and gym lessons, song-learning, storytelling with instruments, story-reading or the Art Club. With the exception of the Art Club, which is held by an external art teacher, all activities are carried out by the facility teachers. For most of the activities tables and chairs are cleared to the side and the children sit on the floor and not, as I am used to as an Austrian kindergarten teacher, in a chair circle.

It is notable that the topics of the guided activities often have a kind of project character. This means they relate to a certain topic not only once, but in many different ways over the course of a few weeks. A good example to demonstrate this project character is the story of William Tell in the DonDon group. First the story of William Tell was told with a picture book, then with music on a CD and then as part of a rhythmicity unit. A few days later the story was told together with the children and the use of instruments, which ended in the development of a musical piece with rhythm instruments. This in turn was used to prepare the children for a festival at the facility, where they marched with drums in the playground and performed the rhythm which they had learned. A lot of activities had William Tell as their main theme, and the children learned not only the actual story but also a good deal about Switzerland, the country of the protagonist's origins, such as how Swiss people live, what they eat or how to greet someone in Switzerland. Furthermore they learned the correct handling of rhythm instruments, reading and singing notes and much more through the different activities around William Tell. In using the story and its thorough and extensive processing the children were challenged and facilitated in their development in a variety of ways.

Before lunch, all tables and chairs are set up and cleaned by the teachers and children in each group room. Then they wash their hands and search for their assigned seat while the tōban distribute the food. After everyone is seated, the teacher plays a few chords on the piano and the tôban ask the routine questions: 'Did you wash your hands? Did you go to the toilet? Enjoy your meal!' Lunchtime is usually quite noisy because the children chat with each other animatedly. They do not seem to feel disturbed by all the noise and finish up everything. The fast eaters wait patiently for the slower ones and no one leaves his or her seat before everyone has finished eating. The children finish lunch together with a chorus of 'gochisōsama deshita, ${ }^{5}$ and clear away their plates. The food for snack times and lunch is prepared directly in the facility by its own team of chefs on the basis of a specially designed plan from a nutritionist and adjusted to the needs of the children. The food plan includes seasonal fruits and vegetables as well as special treats like small sweets. 
Nap time takes place inside every group room after lunch. The teachers and children clear away the tables and chairs, sweep the floor and spread out the futons. Each child has his or her own futon provided by the hoikuen and bedding brought from home at the beginning of the year. After cleaning their teeth and putting on their pyjamas, the children gather in the middle of the small futon camp while the curtains are drawn. One of the teachers reads a short bedtime story and then the children lie down in their beds. While relaxing classical music is playing quietly in the background, the children lie on their futons and are led into sleep by the teacher's light or medium tapping on their back or stroking of their head. The tapping motion seemed quite strange to me at first, as I was more used to light stroking motions and felt that constant tapping would be more of a hindrance than a help for sleeping, but it turned out to be an extremely effective way to induce sleep in the children. The tapping is like the imitation of a heartbeat and seems to make the children remember their time as an embryo in their mother's womb, one of the teachers told me once during nap time. If one looks closely at Japanese everyday life, it is customary among mothers to pat their babies on their back rhythmically in order to calm them or rock them to sleep (Ben Ari 1996:140). Children who have difficulty falling asleep wait patiently for one of the teachers to join them on their futon to help them find sleep.

The goal of nap time is to give the children time to relax thoroughly and to recover from the rigours of the morning so that they can start fresh into the afternoon playtime. The teachers of the group are always present during nap time and complete jobs such as writing short messages to the parents in the children's notebooks. ${ }^{6}$

The children are woken every day at half past two by the same lively and cheerful tune which echoes through the speakers of the hoikuen and the opening of the windows to let in fresh air. They stow away their futons and pyjamas, dress themselves and start the afternoon with a short period of free play outside before the afternoon snack is served. Some children are happy to keep lying on their futon while watching the other kids prepare themselves or the teachers who are cleaning up the room. They are always given enough time to wake up and begin the afternoon at the facility at their own pace.

The afternoon snack at about three o'clock is mostly some kind of little treat like meronpan メロンパン, ${ }^{7}$ sponge cake or onigiri 御握, ${ }^{8}$ which is served with milk or cold tea. After the snack, a short, guided activity takes place in which the teacher

6 The notebooks were calendar and diary in one. Every day a small stamp or sticker was fixed in the calendar to keep a record of every child's attendance. The short notes written in the notebook were messages to the parents, such as praise for their child's achievements, stories about the child's day at the facility or remarks about difficult situations the child faced that day.

7 A sweet baked confection with a bread-dough interior and a cookie-dough crust with ridges resembling a muskmelon.

8 Rice balls. 
mostly reflects on the content of the morning's guided activity together with the children. Within a short period of about ten minutes, new knowledge or rules from the morning session are repeated and reinforced. If, for example, a disaster exercise is held in the morning, the rules for proper behaviour in such cases of emergency are run through in the afternoon. In this particular case, I noticed that the reflection and repetition in the afternoon offers the perfect opportunity to really internalise important rules and bring the information home to the children. The repetition of certain content is not pushed to the point of exhaustion but always used selectively, in the special case of disaster control once a month. But the afternoon activity is not only used for reflection on newly learned information. During this time the children also have the chance to talk about things and situations they experienced during free play, to sing songs or to discuss problems that occurred during the day. Together with the teacher they work out solutions for these problems in conversation. What happened, why did it happen, was it pleasant or not, what could be done to avoid such situations in the future: these and similar questions are asked by the teacher. She offers no concrete solutions but motivates the children to think about the topic discussed by themselves.

For the subsequent farewell ritual the children gather again inside or in front of their group room at about four o'clock. The same farewell song is sung every day, then the children thank the teachers and tóban for the fun day they spent together. This is followed by the customary bow to end the day together and soon afterwards some children are picked up by family members.

After the farewell ritual another phase of free play follows outdoors and the children can be picked up from their family members during this time. They get their bag from inside, bow goodbye once again to the teachers and are on their way home. The remaining children play outside until their parents come. Most children are picked up by half past five.

\section{Facilitating child's development}

Here I want to go deeper into detail about when, where and how concrete facilitation is applied in everyday situations in Minami Ōsawa Nursery School and what areas of child development are challenged and facilitated. Facilitation is creating a suitable framework to enable a child to develop freely, oriented to its individual needs. The conditions of facilitation are subject to the educational views of the respective institution and/or educator, as well as the social norms and values of the culture (Hartmann and Stoll 2006: 131-37; Hobmair 1996: 324-26; Zeissner 1996: 94-96).

Here, the term facilitation is synonymous with assistance and encouragement, consisting of conscious and unconscious factors that promote child development. I chose these terms to illustrate the children's own learning and development impulse 
as well as the low-key but still ever constant presence of the teachers on the different paths of development of their charges.

The areas of human development in preschool age are widespread and versatile. For that reason, the complex development areas in this paper are based on the classifications of educational and developmental psychology studies (Hobmair 1996: 253; Mietzel 2002: 99-175) and divided into three main categories, which are as follows:

1. cognitive development

2. social-emotional development

3. motor development

Even if the slogan of Minami Ōsawa Nursery School would suggest the prioritisation of the third category of motor development, the main focus was on the encouragement of social-emotional development, as can be seen from reading the facility's concrete values and the following pages. This special focus on one of three development areas is, among others, based on the personal views of the hoikuen team, which considered the social-emotional development of children as particularly important. Keeping in mind this aspect, one quickly realises that the facilitation of social and emotional skills finds a place in the entire daily routine of the Minami Ōsawa hoikuen. But first I want to start with the encouragement of cognitive development in Minami Ōsawa Nursery School.

\section{Cognitive development}

The cognitive development of a human being takes place in a social and cultural context. A child saves the information it collected in dealing with its surroundings in everyday life through various experiences and adventures and thus expands its horizon of knowledge. Through intensive play and engagement with its environment, the child's creativity, imagination, spontaneity and flexibility are encouraged. In addition, its attention span, memory, planning and orientation, as well as the will, reasoning and introspection are trained (Hendry 1986a: 1-2; Hobmair 1996: 253; Mietzel 2002: 26-28, 181-95; Zeissner 1996: 94-120).

Another important element included in cognitive development is motivation. The children at Minami Ōsawa Nursery School basically play on their own terms because they are free from restrictions imposed by the teachers and are able to decide when, where and for how long they want to engage in something. This motivation from the inside, to busy oneself with something or to play with others, seemed to result in an accelerated occurrence of intensive free play and a simultaneous facilitation of a holistic development. The development of one's own willingness to do or not to do something is of essential importance for motivating learning and achievement among the children later in school (Hobmair 1996: 253). 
An equally important part of cognitive development is language, as a child deals with itself and others verbally. It keeps in touch with its environment, identifies objects and things, expresses its thoughts and emotions as well as desires with the help of language. Thus language is one of the most basic tools of people to express themselves and to cope in everyday life (Mietzel 2002: 252-53; Hobmair 1996: 253).

Language takes a high priority in the daily routine of the facility, as much of the communication is verbal. Especially the periods of free play offer a fertile ground for the children to experience with all their senses and to share these experiences with their peers in order to understand and learn. In this rather long period in the daily routine the children train their speech comprehension and use of words by actively communicating with their friends and teachers. They chat and joke, sing and discuss. With every teacher-guided conversation, every experience of conversations with other, sometimes older children, the Japanese vocabulary is brought closer to the children. They not only learn new vocabulary but also the appropriate use of new words and expressions.

A conspicuous talent of many children in Minami Ōsawa Nursery School lies in their pragmatics, their talent to effectively bring their ideas, intentions and wishes home to others and to enforce the implementation of their own interests. I remember very vividly the following episode with an earthworm, which illustrates this ability very well:

After a few rainy days the children of the DonDon group searched the playground for play possibilities and found a worm on the sandy ground. Tomoya grabbed it and absolutely refused to pass the worm to the other interested children. A discussion arose between the children but ended fruitlessly for everyone but Tomoya, so the others were forced to look for other entertainment options. Two girls however, Aoi and Kyōmi, remained close to the boy and started talking loudly after a short time span. They talked about the poor earthworm ('kawaisō na mimizuchan' 可哀想な蚯蚓やん) that would surely die soon at the hands of Tomoya and about how one could help the poor animal. Tomoya demonstratively turned his back to the girls, but remained standing near them in order to listen to them. Aoi and Kyōmi seemed to notice this, because they consulted further about what the earthworm would need in order to survive. During their conversation they turned towards Tomoya and finally asked him directly if he did not want to build a house and look for food for the earthworm. After a short silence Tomoya nodded but still did not move. Aoi looked briefly around the playground and finally asked with a grin, whether the red wheelbarrow near the main entrance would not be perfect for a worm house. A few prompts followed from the girls for Tomoya to go and get the wheelbarrow. He could leave the worm in their care meanwhile, they told him, and promised to help him find food and a bed for the animal (my notes). This seemed to convince the boy and he handed the worm over to Aoi with the request that she should watch the worm for a short while ('ki o tsukete ne' 気を付 けてね) while he got the wheelbarrow. While Tomoya was away the girls looked at and touched the earthworm with apparent enthusiasm. They had reached their goal of holding the earthworm in their own hands and seemed visibly satisfied with their success. When 
Tomoya came back with the wheelbarrow, the worm was placed inside it and together the three children searched for all kinds of material to build a nice home for the animal.

Aoi and Kyōmi understood they should wait for the right time and use their language as well as their patience and empathy tactically so as to reach their goal. With the help of their skills in pragmatics the girls achieved what the other children had not managed previously with loudness and intimidation and so could also enjoy the earthworm for entertainment even if not, as initially wanted, claiming the worm for themselves. At least a good compromise for both parties was found and harmony in interpersonal relationships preserved, which ranks highly in the opinion of the hoikuen's teachers.

Singing songs is especially liked by children as a supporting medium of language development. Not a day passes without at least one or two songs being sung in the playground without any initiation from a teacher. Through regular repetition of the songs, the children not only widen their vocabulary but also train their memory skills (Mietzel 2002: 204). The guided activities in the morning basically include a comprehensive facilitation of the children in their cognitive, social and emotional and motor skills. In these units, among numerous other things, stories are read and worked out, pictures and other works of art are created, and dances and songs are learned. The cognitive aspects of facilitation in turn include linguistic development through learning and using new words and expressions as well as taking part in group discussions on specific topics. Auditory perception and its development is a further fundamental component in these activities. Calm, focused listening and conscious perception of spoken language is as important as the training of the right response to acoustic signals, for example, to switch from standing to sitting or to respond properly to prompts during a musical rhythmics unit.

The extension of the child's knowledge horizon appears to be an almost trivial consequence to the observer. It seems rather that fun and enjoyment in active doing are of foremost importance and that the actual expansion of knowledge is carried out hand in hand with creative acting.

Experiences drawn from free play or the guided activities are regularly discussed in the afternoon in the form of a short reflective conversation and thus the children's memory is trained. With the help of these short conversations the children learn to remember past happenings, to talk about experiences using their own words, to listen and to work out possible solutions to problems through consultation in the group. Within this short unit of five to ten minutes the children therefore receive impulses in training their cognitive skills, which include among others memory, language, auditory perception, awareness and problem-solving as well as conflict resolution. 


\section{Social-emotional development}

The social and emotional development of a child is one of the most important principles of human development. By reaching out to other people the child gains experience in how to deal with others. In dealing with others the child is facilitated in its development of empathy, but also in its assertiveness, and learns to respect rules and to deal with frustration (Hamatani, Ōwada and Fujisaki 2001: 4-5; Hayashi, Karasawa and Tobin 2009: 41-42). The child experiences the different facets of human emotions, such as joy, grief, frustration, compassion, envy and affection and learns how to deal with those feelings (Hobmair 1996: 253). The social and emotional strengthening of character is essential in dealing with others and represents a rich soil for positive and also negative experiences in a child's and later adult's everyday life. According to the director of Minami Ōsawa Nursery School the promotion of social competence (yutaka na shakaisei o hagukumu 豊かな社会性を育む) ranks first in the facility. Social competence refers to

the availability and application of cognitive, emotional and motor skills that lead to a longterm favourable rate of positive and negative consequences in certain social situations (Hinsch and Pfingsten 2007: 82).

Put simply, social skills in preschool age can also be equated with being liked and respected by other children, thus being able to communicate with them effectively (Hubbard and Coie 1994: 3). The term 'social competence' refers to numerous characteristics, the shaping of which begins in childhood but may be cultivated further and changed over the span of a whole life. Self-confidence and self-discipline, an appreciation of self and of others, basic trust, team and conflict resolution skills, a sense of responsibility and respect, the ability to co-operate and communicate as well as empathy are included among the main characteristics of building social competence in preschool children (Ben Ari 1997: 138; Hendry 1986b: 56; Mietzel 2002: 219; Rothbaum et al. 2000: 1129-31). The MHLW defines social competence as being able to make friends with others (mijikana hito to shitashimu 身近な人之 親しむ) and to deepen relationships (kakawari o fukameru 関わりを深める), as well as being able to love and trust (aijo ya shinraikan o motsu 愛情や信頼感を持 つ) (Ministry of Health, Labour and Welfare 2008: 15).

As mentioned beforehand, the main focus in Minami Ōsawa Nursery School lies in the social-emotional development of children. Free play sessions offer a lot of room to facilitate the development of the children's social-emotional skills, because while playing a child has the chance to quarrel with others and to release feelings like aggression and frustration. It learns to communicate and co-operate with others, to distinguish between mine, yours and ours, to stand on its own but also to define itself as part of the group (Horino, Kazuhiro, and Yoshizaku 2000: 132; Lewis 1995: 23; Ministry of Health, Labour and Welfare 2008: 6; Tobin, Hsueh and Karasawa 
2009: 156). The various play situations in Minami Ōsawa Nursery School's playground offered boundless possibilities for the children to measure their skills with others, to explore the limits of their own bodies and to strengthen their selfconfidence and assertiveness.

The children of the DonDon group were not afraid of exploring new things and trying them out. With visible motivation they climbed around everywhere they could, drove around with scooters at breakneck speed, quarrelled and reconciled themselves, wanted to play alone and a few minutes later together with their peers again. They could act out their current feelings and needs, but were always aware of the fact that they were not alone in the hoikuen but surrounded by many other children.

Co-operation is not always an easy feat for children in preschool age to accomplish and of course there were also conflicts and disputes among the children at the facility whenever it came to the distribution of toys or the order in which they used special playground equipment. In most of the cases I could observe, fights and disagreements among the children were solved without any help from the teachers. Most of the time one or two children played the role of mediator and searched for independent solutions for each situation together with the other children involved in the dispute. ${ }^{9}$ A teacher intervened only in extremely rare cases and only if explicitly asked for help by the children. Because of the teacher's rather low-key position of observation in the playground, the children seemed to tend to seek help first in the closer and more active environment of their peers. This phenomenon was also observed by Lewis, who holds the view that muting adult authority and giving a central role to children's own problem-solving and reflection is an important factor for the children's accumulation of thoughtfulness and co-operation (Lewis 1995: 102). Hayashi, Karasawa and Tobin also point this out (Hayashi, Karasawa and Tobin 2009: 44).

A special kind of facilitation of this self-help amongst peers is represented by the tōban system (Lewis 1995: 102). In principle, the tasks of the two tōban in Minami Ōsawa Nursery School were confined to the happenings in the group room, but the children who held the function of toban during the day occasionally also fulfilled their duties outdoors during free play and contributed to the resolution of conflicts.

The tōban system is of great importance for social-emotional development because it not only strengthens the children in their understanding of a sense of duty but also in their perception of themselves versus the group and the understanding of authority. The tasks of the töban are designed so that the children are bearing responsibility but are not overwhelmed by it. The role of a tōban is carried out by the children enthusiastically and they clearly enjoy being responsible for the group for

9 For further information about children's responses to conflict and disputes, see Zahn-Waxler 1996: 246770. 
one day. Being a tōban not only strengthens the children in the understanding of a sense of duty, but also in their perception of themselves to the group and teachers. They learn what it is like to be in a position that is not the same as their peers and to take responsibility. They learn how to deal with setbacks when the group does not do what is wanted of them, such as listening quietly or answering loudly and clearly when the two tōban ask a question (Lewis 1995: 105-107). The tōban system facilitates the children not only in the building of self-discipline, perseverance and their sense of duty but also in their empathy and self-confidence (Ben Ari 1997: 102-103; Hendry 1986a: 170). The position also strengthens the children in their sense of responsibility towards the group, which is subsequently reflected in shüdan seikatsu 集団生活, 'life in the group'.

Shüdan seikatsu plays an important role in Minami Ōsawa Nursery School. Materials in the playground and in the group room are taken out and put back together as well as tables, chairs and futons. The children take care of tasks like quieting the group if needed or helping each other with putting on their pyjamas or independently folding an origami fish in Art Club.

Life in the group is brought even more closely to the children through joint lunch and snack times. They perceive themselves as part of the group and experience the joy in collective action by the joint implementation of rituals and routines. Rituals take on a high priority through the course of a day in the hoikuen and in addition encourage the training of memory and particularly the social skills of the children. The joint completion of the daily rituals such as the morning greeting, lunch time and preparation for nap time help the children in their perception of being a part of the group. They play, eat, sing and sleep together, so their understanding of 'I' and 'we' is trained in particular. Strengthening the children's sense of 'community' and encouraging them to be well integrated into the group is an official goal set by the MHLW and is very important for later life in Japanese society. Preschool children are challenged and facilitated in their building of respect, empathy and selfdiscipline every day through the promotion of group life and the active participation in shüdan seikatsu (Ben Ari 1997: 56, 76-77; Hendry 1986a: 169; Peak 1989: 96-98; Rohlen 1989: 20; Schubert 1992: 106; Tobin, Wu and Davidson 1987: 543).

Through the regular routines and rituals the children also experience emotional stability. Their strong attachment to the teachers and their peers is particularly apparent during nap time whenever they seek physical contact with their bed neighbours or the teachers and obviously enjoy being cuddled and stroked in order to help them sleep. In this phase in the daily schedule one of the special characteristics of a hoikuen becomes apparent: the facility should provide the children with a warm, welcoming and relaxing environment.

In the afternoon, right before the farewell ritual, there was always a short unit of five to ten minutes, which was often used for common reflective conversation about the day's events. The children shared their experiences, and problems that had oc- 
curred throughout the day were also addressed. Together with the teacher they reflected about situations that were pleasant or unpleasant and discussed how the different parties perceived them and how such situations could have been dealt with differently or avoided. The teacher offered no concrete solutions but encouraged the children to think about the topics for themselves instead by asking questions such as: 'What did you think of this situation?' or 'What did you feel? Was it enjoyable? Did it annoy you?' The children expressed their feelings of anger, frustration, joy and understanding in front of the group and supported each other in the common search for suitable options to solve the discussed problems. That the children also consciously perceived the content from the afternoon talks could be seen clearly on the days following such discussions, as the children implemented the discussed, learned and reflected topics and problem-solving directly and creatively during free play.

These short conversations train the children not only in cognitive areas, but to a large extent in their social and emotional development as well. They learn to respect each other and to listen, to value the opinions of others, to work together as a group and to find compromise solutions. In particular the development of communication skills, conflict resolution skills and co-operation are facilitated during these minutes.

What is interesting is that the hierarchical structures as well as the autonomous behaviour of the children seem to reflect those of the teachers. Guidelines and specifications from the director or head teacher are listened to and accepted, but plenty of room for individuality in the implementation of the tasks and instructions still remains. The teachers, for example, get exact information on issues and procedures from the director but are rarely supervised. The children are given rules which are to be obeyed as well but the basic framework in which they can move around during the day is characterised by a great deal of freedom.

\section{Motor development}

A child's healthy physical development is fundamental to a positive cognitive development, and the co-ordination, skill, strength and stamina of the growing child should be already facilitated from an early age. By being able to live out their natural urge to move and to measure their strength with others, children are facilitated in both the development of their gross and fine motor skills (Hobmair 1996: 253; Zimmer 2001: 33-35). Active participation in everyday life not only supports the development of synapses in the brain, but also the development of positive feelings in dealing with others (Zimmer 2002: 19-23). The training of fine motor skills in turn is important for later school life, for example, in holding a pen correctly in order to write or in mastering work that requires dexterity.

During free play the children are constantly on the move as the extensive playground offers a variety of opportunities to actively engage and refine their gross 
motor skills. The monkey bars, slides and swings are always in use, as well as the sand box, the tricycles and scooters. The children run, balance, climb, jump and explore their own physical limits. However, the playground does not only offer ample opportunities for the training of gross motor skills but the fine motor skills are also trained during free play at the children's own initiative. An example could be the collecting of fine pale sand and using it as 'sugar icing' for mud pies or as gold dust for a pirate's treasure chest.

During guided activities the motor skills, which were already required during free play, are refined. In a rhythmic lesson the children had the task of moving their bodies according to different rhythms and music. This was not an easy task, because they had to portray different animals, and the teacher often played the piano tunes especially slowly. Movements carried out quickly and easily during free play had to be made at a painstakingly slow pace, which put the children's balance especially to the test. The rehearsing of dances, particularly for festivals, was also regularly on the hoikuen's agenda and trained the children's sense of rhythm as well as their coordination abilities. A special motivating factor was that the dances were performed in public for the parents and of course that animated the children to show extra effort during rehearsals.

During gym lessons, which mostly have a rhythmic background, the children are made aware of the movements of their body. They learn to perceive their body with all their senses and to use it in tune with stimuli from the environment. ${ }^{10}$ The aspect of vision is of great importance here, because the children are responsible for watching out and for not restricting other children with their movements during the gym units as well as in the playground. Through carrying out such lessons the children learn that they are free to move around as they desire but also have to take their peers, the group, into consideration in order to avoid accidents.

In Minami Ōsawa Nursery School, the fine motor skills are trained in various ways such as paper folding, drawing complex subjects or learning the triola. A special training of fine motor skills was held during the Art Club:

During one unit the children had to draw a rain picture and everyone was given a blue sheet and crayons. The art teacher showed the drawing of several possible motifs such as a frog, small snails or hydrangeas on his sheet and instructed the children to draw some of the motifs on their sheets as well. The children painted their pictures precisely and with extreme concentration before they approached the teacher's desk in order to make the raindrops. These were made with a piece of string, which was dipped in white paint and then stretched over the drawing. The children held the string, moved it away from their picture a bit and then let go abruptly to create fine rain lines and drops (my notes).

10 For further information about the relationship between gym lessons, free play and children's motor development, see Bostelmann 2008: 60-61, and Zimmer 2001: 36-40. 
In one lesson they practiced not only the correct holding of crayons, but also their pincer grasp and the co-ordination of visual impressions with their fine motor system as well as training their memory in order to capture seen objects on paper. Daily activities such as the mastering of eating with chopsticks also facilitate the children's development of fine motor skills.

\section{The importance of a child's autonomy}

In Minami Ōsawa Nursery School, the children get numerous chances to develop and refine their skills and interests in an autonomous fashion that matches their individual stage of development, a consequence of the long phases of free play and the broad variety of rituals as well as the participation in guided activities. Despite the freedom the children have, they are aware of their role as a member of the group and are able to meet the requirements for shüdan seikatsu. These requirements include the perception and performance of the role of a töban, co-operation and communication with others as well as awareness of the rules and empathy.

A preschool facility should recognise the children as 'part of a family' but treat them as a 'member of society' (Meirieu 2012: 28). Finding one's way in the group, building trust and orienting one's actions against others as well as co-operating with others are not only of importance to preschool children; even during their later school career and in adulthood a high degree of social competence is required.

Since the goals of day-care centres are strongly based on those of the MHLW, which places emphasis on social-emotional education, the work focus of hoikuen has not changed much through the years and this fact is in turn reflected in wellestablished educational views (see Shakai fukushihōjin kuzuryūkai 2010, \# hoiku mokuhyō nado). ${ }^{11}$ In order to ensure positive learning and growth it is necessary to give children a high degree of autonomy. Particularly during free play the internalisation of Friedrich Froebel's view on the importance of play is crucial, as

play is the highest expression of human development in childhood for it alone is the free expression of what is in a child's soul...children's play is not mere sport. It is full of meaning and import (Froebel 1903: 22).

Maria Montessori's principle 'help me to do it myself' also has an important role in free play. Especially in view of Montessori's pedagogy, ${ }^{12}$ it was interesting to observe the children taking in the roles of both learner and teacher during free play. They learned more actively from each other than from the teachers. This mutual

11 Explained in the section 'Minami Ōsawa Nursery School' in this paper.

12 For further information on Montessori's educational philosophy and pedagogy, please refer to Montessori 2011. 
learning is beneficial in that we only learn when we learn from others and only if we allow it. During the day at the facility the children compare their way of thinking directly with that of the other children.

They learn through intensive play with their peers as well as free and needsoriented engagement, which takes place at their own pace, and build on their existing skills through trial, failure and success. The long, extended free play period and the profound experience of shüdan seikatsu enable the children to show clear improvements in the three mentioned areas of cognitive competence, social-emotional and motor development (see Wustmann 2012: 6). Besides autonomy, the child's motivation is also rooted to a considerable extent in orientation towards one's peers, or in other words, in group life. Children need time and space to let their imagination roam (McLean 2012: 22), and these days, where an excess of training and facilitation threatens to take place, they need plenty of time in which they can decide on activities autonomously (Hartmann and Stoll 2006: 193-194).

In principle, a kindergarten should

[e]ncourage the children to grow, open up new horizons for each child and thus give them the opportunity to enrich themselves and to feel free in the family, the community and society (Meirieu 2012: 28).

In Japan as well as in Austria the daily routine in day-care facilities is divided into times of free play and guided activities as well as special daily rituals, like lunch and nap time. Taking this into account, it can be said that the educational framework in both countries does not differ much from each other; how the work of the teachers is perceived, however, is a different matter altogether. What is currently particularly striking is the gap between what society and politicians perceive as a child's basic needs and what children really need. While most of the Japanese parents want their child to make friends in kindergarten and to take an active part in shüdan seikatsu, Austrian parents often seem to fear that their child is not facilitated and trained adequately and thus is going to fail in its academic career.

However, children's heads should not be filled with ambitious educational plans and facilitation measures in preschool education, because it is more important to pay attention to what children want to learn with enthusiasm and the right proportion of proximity, solidarity and freedom (Repolust 2010: 25):

[Children] need an environment in which they can learn to reach out to others and to take initiative, in which they develop their own ideas and confront their views with that of their peers, in which they develop goals and rules through play independently and deepen their relationship with other children. Children need an environment in which they can learn to find their own way with 'self-will' and make as well as negotiate individual decisions with peers and adults (Colberg-Schrader, Krug and Pelzer 1993: 348). 
Preschool facilities in Japan and Austria are not schools, and all work in the facilities should be used to develop and facilitate the basic skills of the children, to pick them up at their individual development level and to see their talents and not their deficits. It is the duty of educators and the government to create suitable conditions that provide children with a needs-oriented and flexible environment in which they can continue to develop in the best possible way of their own accord. Overly structured training units are neither child-oriented nor do they make sense in any other respect.

It is particularly important in a day care centre to be aware of the importance of care and education, for care and education are interdependent. Care forms the basis on which education can begin. Thus basic human needs are perceived and relationships maintained through care-both important prerequisites for educational processes to occur and succeed (Eder 2009: 7; Milotay 2011: 25).

\section{Conclusion}

Japanese parents can choose between two forms of facilities for their preschool-aged children: the yōchien and the hoikuen. While a yōchien is opened only half a day, hoikuen care for children all day and thus education and care are equally important in the latter.

Since the objectives of Minami Ōsawa Nursery School are strongly oriented on the goals of the MHLW, which sets a high value on social-emotional education, the work focus of this hoikuen has not changed much through the years. This in turn is reflected in well-established educational views. It is through this consistency in the specifications of the MHLW that teachers have a lot of flexibility to pick up the children at their individual stage of development. Time can be put to good use for an intensive examination of the facilitation of a child's basic skills, which are rooted in the social-emotional area in particular.

The needs and wishes of the parents and of the state for hoikuen and yöchien do not lie in the academic education of preschool children, but in free play and the promotion and strengthening of social skills, so that the children are able to gain a good basic knowledge about interpersonal relationships, co-operation and adaptability as well as empathy. The long days spent in a hoikuen, the daily routine and the educational work of the teachers have great influence on the children.

In the case of Minami Ōsawa Nursery School it is the self-proclaimed mission of the director and the teachers to create an environment in which the children develop in the group according to their needs and of their own accord. This goal is consistent with the requirements of the MHLW, which places particular emphasis on welltrained staff and the promotion of social-emotional skills. During my internship at 
the facility, I watched a variety of possibilities in the facilitation of child development in the daily routine and the pedagogical work.

In cognitive development, children are facilitated in their linguistic development through the teacher's guided activities and joint discussions in the afternoon. During those units they are also trained in their auditory perception, concentration and selfdiscipline. A conspicuous talent of many children in Minami Ōsawa Nursery School lies in their pragmatics, in other words their talent to effectively bring their ideas, intentions and wishes home to others and to enforce the implementation of their own interests, as the episode with the earthworm showed us. Regular repetition of learned topics and audible orders with the help of music and tunes strengthen children's cognitive abilities as well. Specifically in the reflective discussions in the afternoon, a high level of memory skills as well as the verbal replay of experiences by children is required. At the same time the children listen to each other and learn to consult on - and find solutions to - problems with their group members, while the teacher is cautiously guiding the discussions.

The main focus in Minami Ōsawa Nursery School lies in the social-emotional development of the children. This special focus is, among others, based on the personal views of the hoikuen team, which considers the social-emotional development of children as particularly important. During free play the children interact with their environment and train their empathy and perseverance, control of behaviour and tolerance of frustration by playing with others. Through the children's examination of 'I' and 'we', the creation of social competence is facilitated, which in turn holds a special significance for the facility director, Mrs T. Especially during the morning hours of free play the children are offered enough space to play out conflicts and release feelings such as aggression. They learn how to communicate with each other, to co-operate, to stand up for themselves, but define their own self as part of the group. Despite the freedom that the children have, they need to learn to be aware of their role as a member of a group and meet the requirements of shüdan seikatsu.

The children of Minami Ōsawa Nursery School show high competence in the settling of disputes. Since the teachers take up a supporting and observing role or the role of a motivated play partner, but never intervene immediately, the children are used to acting as mediators between two quarrelling parties. The tôban system is of great importance for the social-emotional development of the children, because it strengthens not only their sense of duty, but also their perception of themselves against the group and their understanding of authority. They have to practice selfdiscipline, work on their assertiveness and always be aware of their duties. In addition their empathy and self-confidence are strengthened.

The third area in which the children are facilitated and trained in is the development of motor skills. During free play the children are constantly on the move because the extensive playground offers various ways to actively engage in physical experiments and to practice their own abilities, thus improving their gross and fine 
motor skills. During guided and daily activities a refinement of motor skills and body awareness, co-ordination ability and sense of rhythm is taking place.

Thus a holistic development of the children is being facilitated throughout the whole day in Minami Ōsawa Nursery School. Not the pursuit of academic skills ${ }^{13}$ but rather the building of basic human and social skills is the main goal. The children constantly contrast their views to those of their peers. They learn through intensive play with others as well as free needs-based activities and secure their previous capabilities through trial, failure and success. Because of the long, extended free play and the intensive experience of shüdan seikatsu the children show a significant improvement in the three competence areas of cognition, social-emotional development and motor skills.

Both MHWL and MEXT are keen on focusing work in the preschool sector on the training of social-emotional competence and not on achievement. For me this is especially interesting, as currently a tendency to lean towards academic and intellectual development in Austrian preschools can be seen. The usefulness of this trend remains open to question.

Preschool facilities are not schools, and therefore it should be the educator's and government's top priority to create suitable conditions for providing children with a flexible and need-oriented environment in which they can continue to develop in the best possible way of their own accord. It is essential to look beyond one's own horizon and at the state of education in other countries without prejudice and with an open mind.

13 There are still kindergartens in Japan that follow a detailed and strict education plan. Private institutions in particular try to advertise their special curriculums in order to win new children. For further information, see Holloway 2000 and Hendry 1986a. 


\section{REFERENCES}

Ben Ari, Eyal. "From Mothering to Othering: Organization, Culture, and Nap Time in a Japanese Day-Care Center." In Ethos, 24/1, 1996, pp. 139-164

Ben Ari, Eyal. Body Projects in Japanese Childcare. Richmond: Curzon Press, 1997

Boocock, Sarane Spence. "Controlled Diversity: An Overview of the Japanese Preschool System." In Journal of Japanese Studies, 15/1, 1989, pp. 41-65

Bostelmann, Antje, ed. Bildungsabenteuer Kindergarten. Lernen in den 6 Bildungsbereichen. Mühlheim an der Ruhr: Verlag an der Ruhr, 2008

Colberg-Schrader, Hedi, Marianne Krug, and Susanne Pelzer. Soziales Lernen im Kindergarten. München: Juventa, 1993

DeCoker, Gary. “Japanese Preschools: Academic or Nonacademic?” In Japanese Schooling: Patterns of Socialization, Equality and Political Control, edited by James J. Shields, Jr. University Park PA: Pennsylvania State University Press, 1993, pp. 45-58

Eder, Birgit. "Vom lieben langen Tag. Kindergartenalltage müssen nicht ewig gleich aussehen." In Unsere Kinder, 2, 2009, pp. 5-7

Froebel, Friedrich. The Education of Man. New York: D. Appleton, 1903

Hamatani, Naoto 浜谷直人, Ōwada Naoko 大和田尚子, and Fujisaki Machiyo 藤崎眞知代. “Kodomo no jikokontorōru no sodachi”子どもの自己コントロールの育ち [The Development of a Child's Self-Control]. In Japan Society of Research on Early Childhood Care and Education, 54, 2001, pp. 4-5

Hammersley, Martyn, and Paul Atkinson. Ethnography: Principles in Practice. London: Tavistock, 1983

Hartmann, Waltraut, and Martina Stoll. Mehr Qualität für Kinder: Qualitätsstandards und Zukunftsperspektiven für den Kindergarten. Wien: ÖBV Pädagogischer Verlag, 2006

Hashimoto, Hiroko 橋本宏子. Josei rōdō to hoiku: Haha to ko no dōji hoshō no tame ni 女性労働 と保育: 母と子の同時保障のために [Female Labour and Childcare: For the Concomitant Safety of Mother and Child]. Tōkyō: Domesu Shuppan, 1992

Hayashi, Akiko, Mayumi Karasawa, and Joseph Tobin. "The Japanese Preschool's Pedagogy of Feeling: Cultural Strategies for Supporting Young Children's Emotional Development.” In Ethos, 37/1, 2009, pp. 32-49

Hendry, Joy. Becoming Japanese: The World of the Pre-School Child. Manchester: Manchester University Press, 1986a

Hendry, Joy. "Kindergartens and the Transition from Home to School Education." In Comparative Education, 22/1, 1986b, pp. 53-58

Hinsch, Rüdiger, and Ulrich Pfingsten. Das Gruppentraining sozialer Kompetenzen (GSK): Grundlagen, Durchführung, Materialien. Weinheim: Beltz, 2007

Hobmair, Hermann, ed. Pädagogik. Köln: Bildungsverlag EINS, 1996

Hoffman, Diane M. "Pedagogies of Self in American and Japanese Early Childhood Education: A Critical Conceptual Analysis." In The Elementary School Journal, 101/2, 2000, pp. 193-208

Holloway, Susan D. Contested Childhood: Diversity and Change in Japanese Preschools. New York: Routledge, 2000

Horino, Midori 堀野緑, Miyashita Kazuhiro 宮下一博, and Hamaguchi Yoshizaku 浜口佳和. Kodomono pāsonariti to shakaisei nohattatsu 子供のパーソナリティと社会性の発達 [The Development of a Child's Personality and Social Character]. Kyōto: Kitaōji-shobō, 2000

Hubbard, Julie A., and John D. Coie. "Emotional Correlates of Social Competence in Children's Peer Relationships.” In Merrill-Palmer Quarterly, 40/1, 1994, pp. 1-20 
JETRO (Japan External Trade Organization). “Child Day Care Industry in Japan.” In Japan Economic Monthly, November 2005, pp. 1-16

Lewis, Catherine C. Educating Hearts and Minds: Reflections on Japanese Preschool and Elementary Education. Cambridge: Cambridge University Press, 1995

McLean, Aileen. "Gemeinsam mit dem Kind.” In Kinder in Europa, 22/4, 2012, pp. 22-23

Meirieu, Philippe. “Ohne Erfolg im Kindergarten kein Erfolg in der Schule.” In Kinder in Europa, 22/4, 2012, pp. 28-29

Mietzel, Gerd. Wege in die Entwicklungspsychologie. Kindheit und Jugend. Weinheim: Beltz, 2002

Milotay, Nóra. "Investieren in frühe Kindheit." In Kinder in Europa, 20/5, 2011, pp. 25-26

Ministry of Health, Labour and Welfare. Hoikusho hoiku shishin 保育所保育指針 [Guidelines for Childcare in Day-Care Centres]. Tōkyō: Furēberukan, 2008

Montessori, Maria. The Absorbent Mind. Oxford: Oxford City Press, 2011

Peak, Lois. "Learning to Become Part of the Group: The Japanese Child's Transition to Preschool Life.” In Journal of Japanese Studies, 15/1, 1989, pp. 93-123

Peak, Lois. Learning to go to School in Japan: The Transition From the Home to Preschool Life. Berkley CA: University of California Press, 1991

Repolust, Christina. "Lernen ist eine Schatzsuche.” In Unsere Kinder, 4, 2010, pp. 24-25

Rohlen, Thomas P. "Order in Japanese Society: Attachment, Authority and Routine." In Journal of Japanese Studies, 15/1, 1989, pp. 5-41

Rothbaum, Fred, et al. "The Development of Close Relationships in Japan and the United States: Paths of Symbiotic Harmony and Generative Tension.” In Child Development, 72/5, 2000, pp. 1121-1142

Schubert, Volker. Die Inszenierung der Harmonie. Erziehung und Gesellschaft in Japan. Darmstadt: Wissenschaftliche Buchgesellschaft, 1992

Shakai fukushihōjin kuzuryūkai 社会福祉法人九頭童会 [Social Welfare Service Corporation Kuzuryūkai]. "Minami Ōsawa Hoikuen”南大沢保育園 [Minami Ōsawa Nursery School]. 2010, http://www.minamiosawa-hoiku.com/index.php?id=14, accessed August 2012

Shakai fukushihōjin kuzuryūkai 社会福祉法人九頭竜会 [Social Welfare Service Corporation Kuzuryūkai]. “Hoiku mokuhyō nado” 保育目標など [Nursing Objectives and so forth]. 2012, http://www.minamiosawa-hoiku.com/index.php?id=13, accessed June 2013

Tobin, Joseph J., David Y. H. Wu, and Dana H. Davidson. "Class Size and Student/Teacher Ratios in the Japanese Preschool." In Comparative Education Review, 31/4, 1987, pp. 533-549

Tobin, Joseph J., Yeh Hsueh, and Mayumi Karasawa. Preschool in Three Cultures Revisited: China, Japan and the United States. Chicago: University of Chicago Press, 2009

Wustmann, Cornelia. "Missverständnisse rund ums kindliche Spiel: Plädoyer für die offenkundige Bedeutung des Spielens oder: ein Versuch, Eulen nach Athen zu tragen." In Unsere Kinder, 3, 2012, pp. 5-7

Zahn-Waxler, Carolyn, et al. "Japanese and United States Preschool Children's Responses to Conflict and Distress." In Child Development, 67/5, 1996, pp. 2462-2477

Zeissner, Georg. Arbeitsbuch Kindergarten. Köln: Stam Verlag, 1996

Zhou, Yanfei, Akiko S. Oishi, and Akemi Ueda. "Childcare System in Japan.” In Journal of Population and Social Security (Population), supplement to vol. 1, 2002, pp. 411-425

Zimmer, Renate. Was Kinder stark macht: Fähigkeiten wecken - Entwicklung fördern. Freiburg: Herder Verlag, 2001

Zimmer, Renate. Schafft die Stühle ab: Was Kinder durch Bewegung lernen. Freiburg: Herder Verlag, 2002 


\section{GLOSSARY}

\begin{tabular}{|c|c|c|}
\hline hoikuen & 保育園 & daycare facility, nursery school \\
\hline Kuzuryūkai & 九頭竜会 & $\begin{array}{l}\text { name of the corporation for social services that } \\
\text { Minami Ōsawa Nursery School belongs to }\end{array}$ \\
\hline meronpan & メロンパン & $\begin{array}{l}\text { A sweet baked good with a bread-dough interior } \\
\text { and a cookie-dough crust with ridges resembling } \\
\text { a muskmelon. }\end{array}$ \\
\hline Minami Ōsawa hoikuen & 南大沢保育園 & Minami Ōsawa Nursery School \\
\hline mochitsuki & 餅付き & $\begin{array}{l}\text { A traditional gathering in January for the hoi- } \\
\text { kuen's families to pound rice cakes and greet the } \\
\text { New Year }\end{array}$ \\
\hline nazenaze & なぜなぜ & $\begin{array}{l}\text { the group of three year olds in Minami Ōsawa } \\
\text { Nursery School }\end{array}$ \\
\hline onigiri & 御握 & rice balls \\
\hline shūdan seikatsu & 集団生活 & group life, living in a group \\
\hline tōban & 当番 & $\begin{array}{l}\text { class monitor; duties include serving of food, } \\
\text { asking routine questions at lunch time and help- } \\
\text { ing the teacher during the day }\end{array}$ \\
\hline yochiyochi & よちよち & $\begin{array}{l}\text { the group of two year olds in Minami Ōsawa } \\
\text { Nursery School }\end{array}$ \\
\hline yōchien & 幼稚園 & kindergarten \\
\hline
\end{tabular}

